\title{
A Review of the Multiple-Intelligence Domains of Physically Handicapped Individuals in Terms of Certain Demographic Attributes
}

\author{
Levent Bayram $^{1} \&$ Ozge Deniz Yuceloglu Keskin ${ }^{1}$ \\ ${ }^{1}$ University of Ondokuz Mayis, Faculty of Yasar Dogu Sports Sciences, Samsun, Turkey \\ Correspondence: Levent Bayram, Faculty of Yasar Dogu Sports Sciences, University of Ondokuz Mayis, \\ Samsun, Turkey. E-mail: levent.bayram@omu.edu.tr
}

Received: September 1, 2019

Accepted: October 6, 2019 Online Published: October 24, 2019

doi:10.5539/jel.v8n6p39

URL: https://doi.org/10.5539/jel.v8n6p39

\begin{abstract}
The purpose of this study is to review the multiple intelligence domains of physically handicapped individuals with regard to certain variables. The population of the study consists of 40 physically handicapped adults in total, 13 females and 27 males, between the ages of 16 to 58 with an age average of $30.80 \pm 9.78$ who were members of Association of the Physically Handicapped and who participated into the study voluntarily in Samsun province, in 2017. In addition to the descriptive questions about age, gender, educational background and whether they did sports or not, "Multiple Intelligence Inventory" developed by Gülşen (2015) was applied to the respondents in order to obtain data. In the study, $t$ test and Mann Whitney $U$ test for the paired comparisons, and Kruskal Wallis and One Way ANOVA test for the triple comparisons and above were used to compare multiple intelligence theory score averages of the physically handicapped individuals in terms of the variables of gender, age, educational background and whether they do sports or not. Level of significance was taken as $(p<0.05)$. It was found that there was a significant difference between the logical/mathematical intelligence domain score averages of female and male participants $(p<0.05)$. It was seen that the logical/mathematical intelligence domain of males was more dominant than that of females. A statistically significant difference was observed at the Visual/Spatial and Musical/Rhythmic Intelligence domains with regard to age group variable $(\mathrm{p}<0.05)$. In addition, when the multiple intelligence score averages were compared according to whether individuals do sports or not, the logical/mathematical intelligence domain of those doing sports was significantly higher than that of those who did not do sports $(\mathrm{p}<0.05)$. The results can be interpreted as that doing sports may develop logical-mathematical intelligence of individuals. The study also shows that none of the fields of intelligence differs statistically in terms of the variable of educational status.
\end{abstract}

Keywords: disability, intelligence, multiple intelligence, physical disability, sports

\section{Introduction}

Today, the concept of "the handicapped" that is one of the words used to express individuals with physiological, psychological and anatomical deficiencies or disablement defines many individuals with special needs having a wide range of disabilities.

Being handicapped is a condition resulting from the physical, mental or psychological differences of function and structure that makes it difficult for the handicapped individual to participate in professional life (Bolderson et al., 2002). Disabilities may sometimes be congenital or may originate later as a result of a disease or an accident as a decrease in various degrees of the physical, mental, psychological, sensorial and social abilities. To a highly considerable extent, it also results in chronic disease (Hahn, 1999). Disability, which also creates barriers in the working capacities and vital functions of the individuals, reduces vital activities partially or fully and most importantly makes it difficult for the handicapped to maintain their social lives without impediments (Barnes \& Mercer, 2005). In this respect, they are the social disadvantages caused by damages in physical functions (Heiden, 1996).

The type of the disability affecting the handicapped individuals is effective on their life styles, habits, interests, daily activities, education levels, the way of perceiving life, the way they approach to the events and their attitudes in social relations. One of the important processes to become an individual is development of intelligence. Individuals adapt to the ongoing dynamics of life in proportion to their intelligence and diversify their behaviors regarding the instincts of existence and survival with their intelligence. They interpret, analyze 
and draw conclusions from their perceptions, experiences and the knowledge they gained through their life with their intelligence. Because of all these, the level and feature of intelligence is one of the main parameters of defining an individual.

Gardner argues that biological and cultural dimensions constitute the basis of his theory putting forth that intelligence consists of multiple components. He thinks that different types of learning take place in different parts of the brain. It is asserted that in addition to biological factors, development of intelligence is related to culture and that the types of intelligence and behavioral patterns that cultures value develop more. Gardner proposes four criteria for a feature to be intelligence. These are: presence of symbols, being valued by culture, mediating the production of goods and services, and ability to solve problems (Bellenca, 1997).

Gardner's model has given a broader meaning to the question of what intelligence is. Gardner (1993), states that the traditional intelligence approach is advantageous in terms of convenience it creates in evaluating students according to a common criterion, but it is not useful in discovering the strengths and weaknesses of the students. $\mathrm{He}$ argues that intelligence has eight components operating independently and that an activity is indeed a combination of several intelligence components.

Gardner's 8 different types of intelligence can be briefly described as follows:

1) Verbal-Linguistic Intelligence: the ability to use words effectively both verbally and in writing;

2) Logical-Mathematical Intelligence: the ability to use numbers effectively and to establish cause-effect relationships and to make effective reasoning about the formation and process of the events;

3) Visual-Spatial Intelligence: the ability to read maps, to draw sketches, to think through pictures and figures and to express oneself in non-verbal forms;

4) Musical Intelligence: the ability to perceive, distinguish and express musical forms;

5) Bodily-Kinesthetic Intelligence: the ability to use the whole body to express emotions and thoughts, to use hands effectively and to produce new things with hands;

6) Interpersonal Intelligence: the ability to understand the emotions, desires, interests and needs of the people around;

7) Intrapersonal Intelligence: the ability to know oneself and to show behaviors accordant with the environment with the knowledge and understanding about oneself;

8) Naturalistic Intelligence: the ability of an individual to recognize living organisms such as plants and animals, to classify them according to their specific characteristics and to distinguish them from others (Gardner, 1999).

Gardner includes access to resources and the social environment in which an individual grows into the environmental factors that support or limit development of intelligence. It is seen that physically handicapped individuals are in a more disadvantageous position than the non-handicapped in accessing and maintaining activities that support their mental development (education, social environment, sports). The findings of Turkish Survey on the Handicapped (Republic of Turkey State Statistics Institute [DIEE], 2002) reveal that people with disabilities live in conditions far from normal life. It is understood that a life away from education and working areas and dependent on others has become the "normal" of the handicapped. It is determined that the handicapped in Turkey are fully isolated from the society apart from the demands of a normal life concept.

The positioning of the individual within the social network is the main reason of the recognition or definition of the handicapped as disadvantageous individuals. In the focus of the sociology of disability, the "state of disability" of the handicapped individuals cause individuals to encounter various impediments in social life, and during these encounters 'the individuals with disabilities' often stay in a more disadvantageous position than the 'others' (individuals without disabilities) they are compared to (Burcu, 2017).

The purpose of this study is to review the multiple intelligence domains of physically handicapped individuals in terms of certain variables.

\section{Method}

\subsection{Sample and Procedure}

This is a descriptive study aiming to examine the multiple intelligence domains of physically handicapped individuals according to certain variables. The study consisted of 40 physically handicapped adults in total, 13 females and 27 males, between the ages of 16 to 58 with an age average of $30.80 \pm 9.78$ who were members of Association of the Physically Handicapped and who participated into the study voluntarily in Samsun province, in 2018. Prior to the study, the respondents have been contacted, detailed information has been given and those 
who were volunteers have been included into the study.

\subsection{Measures}

In order to obtain data, "Multiple Intelligence Inventory" developed by Gülşen (2015) was applied to the respondents in addition to the descriptive questions about age, gender, educational background and whether they did sports or not.

\section{Multiple Intelligences Survey}

This survey was used to find out the students' multiple intelligence profiles. The Multiple Intelligences Survey contained 80 statements, addressing to eight intelligence types. The first category included statements from 1 to 10 addressing, verbal-linguistic intelligence. The second category included statements from 11 to 20 addressing, logical-mathematical intelligence. In the third category, statements from 21 to 30, focused on visual-spatial intelligence. In the fourth category, statements from 31 to 40, referred to musical intelligence. The fifth category included statements from 41 to 50 emphasizing naturalistic intelligence. The sixth category, statements from 51 to 60 , covered interpersonal intelligence. The seventh category, statements from 61 to 70 , addressed bodily-kinesthetic intelligence. Lastly, in the eighth category, statements from 71 to 80 , focused on intrapersonal intelligence.

All questions in the survey were in Turkish. The statements in the survey were based on a 5-point Likert-type rating scale, which were $0=$ the statement does not describe you at all, $1=$ the statement describes you very little, $2=$ the statement describes you somewhat, $3=$ the statement describes you pretty well and $4=$ the statement describes you exactly. The participants were asked to complete the survey by putting a check next to each statement that accurately described them (Subaşı, 2014).

\subsection{Data Analyses}

The data were analyzed through SPSS 22 packaged software. Shapiro-Wilk test was used to determine whether the data showed normal distribution or not. In the study, for the paired comparisons, $t$ test and Mann Whitney $U$ test were used, and for the triple comparisons and above, Kruskal Wallis and One Way ANOVA tests were used to compare multiple intelligence theory score averages of the physically handicapped individuals in terms of the variables of gender, age, educational background and whether they did sports or not. Then, the descriptive statistics (average, standard deviation, median, minimum and maximum values) of the variables were produced. The level of significance was taken as $(\mathrm{p}<0.05)$.

\section{Results}

Table 1. Comparison of the score averages of multiple intelligence types according to gender variable

\begin{tabular}{lllllllll}
\hline Intelligences Area & Gender & $\mathrm{N}$ & Mean & $\mathrm{Sd}$ & Median & Min & Max & $\mathrm{P}$ \\
\hline Verbal-Linguistic & Female & 13 & 30.08 & 8.902 & 3 & 5 & 39 & .475 \\
& Male & 27 & 28.85 & 7.735 & 28 & 9 & 39 & \\
Logical-Mathematical & Female & 13 & 18.92 & 8.077 & 17 & 4 & 33 & $.039 *$ \\
& Male & 27 & 24.30 & 7.151 & 23 & 12 & 36 & \\
Visual-Spatial & Female & 13 & 27.08 & 4.752 & 27 & 18 & 34 & .088 \\
Musical-Rhythmic & Male & 27 & 23.70 & 6.101 & 23 & 12 & 39 & \\
Naturalistic & Female & 13 & 21.69 & 6.550 & 22 & 7 & 30 & .148 \\
Interpersonal & Male & 27 & 18.00 & 7.761 & 17 & 6 & 40 & \\
Bodily-Kinesthetic & Female & 13 & 25.15 & 6.283 & 26 & 13 & 37 & .327 \\
Intrapersonal & Male & 27 & 27.56 & 7.546 & 28 & 12 & 40 & \\
& Female & 13 & 28.15 & 6.706 & 25 & 18 & 39 & .148 \\
& Male & 27 & 31.22 & 4.154 & 31 & 23 & 38 & \\
& Female & 13 & 20.85 & 6.543 & 20 & 11 & 30 & .186 \\
\end{tabular}

Note. ${ }^{\mathrm{p}}<0.05$

In Table 1, a statistically significant difference between females and males is observed in the logical/mathematical intelligence domain of the participants $(p<0.05)$. It is seen that the male participants have a higher average score in logical/mathematical intelligence domain when compared to female participants. 
Table 2. Comparison of the score averages of multiple intelligence types with regard to age group variable

\begin{tabular}{|c|c|c|c|c|c|c|c|c|}
\hline Intelligences Area & Age & $\mathrm{N}$ & Mean & $\mathrm{Sd}$ & Median & Min & Max & $\mathrm{P}$ \\
\hline \multirow[t]{3}{*}{ Verbal-Linguistic } & $16-25$ age & 12 & 25.42 & 10.059 & 25.0 & 5 & 37 & .102 \\
\hline & $26-35$ age & 16 & 31.94 & 4.781 & 32.0 & 26 & 39 & \\
\hline & above 35 age & 12 & 29.50 & 8.372 & 29.5 & 9 & 39 & \\
\hline \multirow[t]{3}{*}{ Logical-Mathematical } & $16-25$ age & 12 & 21.33 & 8.195 & 21.0 & 4 & 36 & .797 \\
\hline & $26-35$ age & 16 & 23.38 & 8.188 & 20.5 & 13 & 36 & \\
\hline & above 35 age & 12 & 22.67 & 7.340 & 20.5 & 12 & 35 & \\
\hline \multirow[t]{3}{*}{ Visual-Spatial } & $16-25$ age & 12 & 28.58 & 5.125 & 27.5 & 23 & 39 & $.016 *$ \\
\hline & $26-35$ age & 16 & 23.75 & 4.420 & 22.5 & 18 & 34 & \\
\hline & above 35 age & 12 & 22.42 & 6.735 & 22.5 & 12 & 34 & \\
\hline \multirow[t]{3}{*}{ Musical-Rhythmic } & $16-25$ age & 12 & 24.00 & 7.286 & 24.0 & 12 & 40 & $.016 *$ \\
\hline & $26-35$ age & 16 & 18.25 & 6.894 & 17.5 & 6 & 29 & \\
\hline & above 35 age & 12 & 15.67 & 6.485 & 16.5 & 7 & 30 & \\
\hline \multirow[t]{3}{*}{ Naturalistic } & $16-25$ age & 12 & 22.42 & 5.900 & 25.0 & 12 & 28 & $.007 *$ \\
\hline & $26-35$ age & 16 & 26.63 & 6.365 & 26.0 & 18 & 40 & \\
\hline & above 35 age & 12 & 31.33 & 6.985 & 33.0 & 15 & 40 & \\
\hline \multirow[t]{3}{*}{ Interpersonal } & $16-25$ age & 12 & 27.50 & 5.535 & 27.0 & 18 & 37 & .088 \\
\hline & $26-35$ age & 16 & 31.75 & 3.821 & 32.0 & 23 & 38 & \\
\hline & above 35 age & 12 & 30.92 & 5.900 & 30.5 & 21 & 39 & \\
\hline \multirow[t]{3}{*}{ Bodily-Kinesthetic } & $16-25$ age & 12 & 23.00 & 7.508 & 22.5 & 11 & 37 & .088 \\
\hline & $26-35$ age & 16 & 25.19 & 5.089 & 25.5 & 13 & 32 & \\
\hline & above 35 age & 12 & 19.92 & 7.833 & 17.0 & 10 & 32 & \\
\hline \multirow[t]{3}{*}{ Intrapersonal } & $16-25$ age & 12 & 26.75 & 4.654 & 27.5 & 17 & 33 & .475 \\
\hline & $26-35$ age & 16 & 25.56 & 2.366 & 26.5 & 20 & 29 & \\
\hline & above 35 age & 12 & 25.17 & 3.353 & 25.5 & 17 & 30 & \\
\hline
\end{tabular}

Note. ${ }^{*} \mathrm{p}<0.05$

When the average multiple intelligence scores of the participants are compared according to the age group variable in Table 2, the score of 16-25 age group in Visual/Spatial and Musical/Rhythmic intelligence domain, and the score of 26-35 age group in Naturalistic Intelligence domain are found to be significantly higher than the others (p $<0.05)$.

Table 3. Comparison of the score averages of multiple intelligence types according to whether the participants do sports or not

\begin{tabular}{|c|c|c|c|c|c|c|c|c|}
\hline Intelligences Area & Sporting Status & $\mathrm{N}$ & Mean & $\mathrm{Sd}$ & Median & Min & Max & $\mathrm{P}$ \\
\hline \multirow[t]{2}{*}{ Verbal-Linguistic } & Sports & 26 & 30.08 & 7.031 & 29.50 & 9 & 39 & .726 \\
\hline & Non-sports & 14 & 27.71 & 9.738 & 30.50 & 5 & 37 & \\
\hline \multirow[t]{2}{*}{ Logical-Mathematical } & Sports & 26 & 24.81 & 7.537 & 23.50 & 14 & 36 & $.017 *$ \\
\hline & Non-sports & 14 & 18.36 & 6.605 & 19.00 & 4 & 29 & \\
\hline \multirow{2}{*}{ Visual-Spatial } & Sports & 26 & 23.88 & 5.861 & 23.00 & 12 & 39 & .088 \\
\hline & Non-sports & 14 & 26.50 & 5.667 & 26.00 & 18 & 34 & \\
\hline \multirow[t]{2}{*}{ Musical-Rhythmic } & Sports & 26 & 19.58 & 7.731 & 18.50 & 6 & 40 & .148 \\
\hline & Non-sports & 14 & 18.50 & 7.314 & 17.50 & 7 & 30 & \\
\hline \multirow[t]{2}{*}{ Naturalistic } & Sports & 26 & 24.96 & 6.533 & 25.00 & 12 & 37 & .327 \\
\hline & Non-sports & 14 & 30.14 & 7.305 & 29.50 & 13 & 40 & \\
\hline \multirow[t]{2}{*}{ Interpersonal } & Sports & 26 & 30.54 & 5.293 & 30.50 & 39 & 21 & .148 \\
\hline & Non-sports & 14 & 29.64 & 5.286 & 30.00 & 21 & 37 & \\
\hline \multirow[t]{2}{*}{ Bodily-Kinesthetic } & Sports & 26 & 23.88 & 7.383 & 26.00 & 10 & 37 & .186 \\
\hline & Non-sports & 14 & 21.21 & 5.860 & 20.00 & 13 & 30 & \\
\hline \multirow[t]{2}{*}{ Intrapersonal } & Sports & 26 & 26.23 & 3.922 & 27.00 & 17 & 33 & .104 \\
\hline & Non-sports & 14 & 25.00 & 2.219 & 25.50 & 22 & 29 & \\
\hline
\end{tabular}

Note. ${ }^{*} \mathrm{p}<0.05$.

In Table 3, the average multiple intelligence scores of the participants are compared according to whether they do sports or not. The logical/mathematical intelligence domain of those doing sports is found to be significantly higher than that of those who do not do sports $(\mathrm{p}<0.05)$. 
Table 4. Comparison of the score averages of multiple intelligence types with regard to educational background variable

\begin{tabular}{|c|c|c|c|c|c|c|c|c|}
\hline Intelligences Area & Educational Background & $\mathrm{N}$ & Mean & $\mathrm{Sd}$ & Median & Min & Max & $\mathrm{p}$ \\
\hline \multirow[t]{4}{*}{ Verbal-Linguistic } & Primary School & 6 & 23.33 & 13.155 & 28.00 & 5 & 37 & .222 \\
\hline & Secondary School & 5 & 27.8 & 2.588 & 27.00 & 25 & 31 & \\
\hline & High School & 9 & 27.44 & 7.860 & 28.00 & 9 & 35 & \\
\hline & University & 20 & 32.20 & 6.110 & 35.00 & 22 & 39 & \\
\hline \multirow[t]{4}{*}{ Logical-Mathematical } & Primary School & 6 & 17.17 & 7.679 & 19.50 & 4 & 26 & .0 .63 \\
\hline & Secondary School & 5 & 21.20 & 3.899 & 20.00 & 17 & 27 & \\
\hline & High School & 9 & 27.88 & 5.805 & 27.00 & 20 & 36 & \\
\hline & University & 20 & 22.15 & 8.299 & 19.00 & 12 & 36 & \\
\hline \multirow[t]{4}{*}{ Visual-Spatial } & Primary School & 6 & 24.17 & 5.382 & 24.00 & 17 & 32 & .390 \\
\hline & Secondary School & 5 & 21.40 & 6.580 & 23.00 & 12 & 29 & \\
\hline & High School & 9 & 27.22 & 8.090 & 26.00 & 14 & 39 & \\
\hline & University & 20 & 24.75 & 4.494 & 23.00 & 18 & 34 & \\
\hline \multirow[t]{4}{*}{ Musical-Rhythmic } & Primary School & 6 & 22.33 & 5.164 & 17.00 & 17 & 30 & .390 \\
\hline & Secondary School & 5 & 15.20 & 6.760 & 17.00 & 7 & 24 & \\
\hline & High School & 9 & 20.89 & 10.362 & 20.00 & 7 & 40 & \\
\hline & University & 20 & 15.37 & 6.692 & 18.00 & 6 & 29 & \\
\hline \multirow[t]{4}{*}{ Naturalistic } & Primary School & 6 & 27.50 & 9.566 & 26.00 & 13 & 40 & .806 \\
\hline & Secondary School & 5 & 29.40 & 5.683 & 31.00 & 20 & 35 & \\
\hline & High School & 9 & 25.56 & 6.579 & 26.00 & 15 & 37 & \\
\hline & University & 20 & 26.45 & 7.323 & 26.50 & 12 & 40 & \\
\hline \multirow[t]{4}{*}{ Interpersonal } & Primary School & 6 & 28.83 & 4.021 & 28.00 & 25 & 35 & .539 \\
\hline & Secondary School & 5 & 30.00 & 4.528 & 31.00 & 25 & 36 & \\
\hline & High School & 9 & 32.44 & 4.613 & 35.00 & 24 & 37 & \\
\hline & University & 20 & 29.70 & 5.966 & 30.50 & 18 & 39 & \\
\hline \multirow[t]{4}{*}{ Bodily-Kinesthetic } & Primary School & 6 & 19.33 & 6.121 & 19.50 & 12 & 30 & .222 \\
\hline & Secondary School & 5 & 20.60 & 5.320 & 19.00 & 15 & 28 & \\
\hline & High School & 9 & 22.67 & 8.930 & 24.00 & 10 & 37 & \\
\hline & University & 20 & 24.75 & 6.340 & 27.00 & 11 & 32 & \\
\hline \multirow[t]{4}{*}{ Intrapersonal } & Primary School & 6 & 25.17 & 2.483 & 25.50 & 22 & 29 & .970 \\
\hline & Secondary School & 5 & 26.00 & 2.915 & 26.00 & 22 & 30 & \\
\hline & High School & 9 & 25.78 & 4.438 & 26.00 & 17 & 33 & \\
\hline & University & 20 & 25.95 & 3.531 & 26.50 & 17 & 33 & \\
\hline
\end{tabular}

Note. ${ }^{*} \mathrm{p}<0.05$.

No statistically significant difference is observed between the groups when the average multiple intelligence scores of the participants are compared with regard to educational background in Table $4(p>0.05)$.

\section{Discussion}

According to the table of analysis (Table 1) that indicates the comparison of multiple intelligence domains in terms of gender, the Logical/Mathematical intelligence domain scores of the male physically handicapped individuals were found to be significantly higher than that of females $(p<0.039)$. In the study conducted by Loori (2005), the logical intelligence domain of boys was stated to be more developed than girls. When the related researches were examined, it was noted that there was a difference between male and female students in favor of males when the changes with regard to gender in mathematical intelligence scores based on multiple intelligence theory were analyzed (Bennet, 1996; Furnham \& Fong, 2000; Doğan, 2007; Demiray, 2011). Male individuals begin to feel the responsibility of social codifications imposed on their gender earlier than female individuals. These codifications include the suggestions made to men at early stages of their lives about that they are adults. In any case, in Turkish society, men take the responsibilities such as beginning to work, joining into the labor force, making financial gains, contributing to maintenance of the family or maintaining the family earlier than female individuals. It is normal for the handicapped individuals who are in the same sociological and cultural structure to feel this effect psychologically. This may lead to earlier development of abilities of reasoning, judgment and analyzing the life and events in men.

When the multiple intelligence domains were analyzed in terms of age variable (Table 2), it was observed that the physically handicapped individuals in $16-25$ age group were statistically significantly superior in the "Visual/Spatial and Musical Intelligence" domains compared to the handicapped individuals in older age groups. 
Visual/Spatial Intelligence is defined as the ability to read maps, draw sketches, think through pictures and figures and express oneself in non-verbal forms. Some of the common features of this age group are that their imagination is highly rich and active, they consider visuality important, they strive to create appreciation on the other party, and they give clues about their inner worlds by reflecting their emotions through body language. Later, while imagination is being replaced by rationality, emotion control will be strengthened and the form of self-expression will no longer be visuality. These individuals are in a period when they may be under the influence of popular music due to their age. New trends emerge suddenly. This creates a dynamic range of music preferences. Older ages are periods that are relatively close to change in relation to music preferences. Adopting different movements is difficult or impossible. Again, in the age parameter, it was seen that the group at the ages over 35 years established superiority in naturalistic intelligence domain in a way to make a significant difference compared to the lower age groups. Almost all of the individuals over 35 years old, today, have experienced and can still remember the times when the city they live in has not entered the process of urbanization and concretion yet and the physical environment has been more natural and untouched. The fact that these individuals lived in rural and natural environment and were under the effect of this environment during the period when the intelligence domains were formed may explain why the naturalistic intelligence scores of these individuals are higher than that of the younger individuals.

When the multiple intelligence domains of the physically handicapped individuals were examined in terms of the state of doing sports (Table 3), it was seen that the group of handicapped people doing sports was superior with a statistically significant difference in the "Logical/Mathematical Intelligence" domain compared to the group that did not do sports $(\mathrm{p}<0.017)$. It can be said that the bodily intelligence is dominant for the people who enjoy doing sportive activities, love physical education courses, do sports such as gymnastics and swimming, even do more than one sport at the same time (Temiz, 2007). When the literature was reviewed, it was also reported in the studies of Hoşgörür and Katrancı (2007) that the students at the department of physical education and sports got the highest average scores in bodily/kinesthetic intelligence domain in contrast to the study herein. In addition, in their study evaluating university students doing regular sports and not doing sports, Ermiş and İmamoğlu (2013) stated that the students doing regular sports had the highest average scores in bodily/kinesthetic and interpersonal/social intelligence domains respectively and also that the state of doing sports was effective in the formation of significant difference in these two intelligence domains. Considering that the students at the department of physical education and sports constituting the sample of this study had sportive backgrounds as well, their scores in terms of the intelligence domains can be thought as an expected result. The handicapped individuals taking part in the study are those who do not have the ability to use part of their bodies effectively and who can carry out both sports and daily activities in more limited forms in their own dynamics. Due to its characteristics, sport is a type activity which is not only effective in bodily intelligence but also effective in other intelligence domains. There is a close relationship between the way individuals use the resources they have and the dominant intelligence area. Developing new solutions that can cope with the situation by people who are not able to perform all the requirements of a sports technique or movement during a competition, seeking a more efficient and strategic way of using the available movement potentials and searching for tactics since it is unlikely to change the result of the match with physical effort may explain the development of logical intelligence domain.

When the multiple intelligence domains were examined according to educational backgrounds, there is no statistically significant difference is observed between the groups with regard to educational background. Despite this, it is seen that average multiple intelligence scores of the individuals who continued their education until graduating from high school had a superiority in logical/mathematical domain compared to those who graduated from primary school, secondary school or university (Table 4). In a meta-analysis study conducted by Kezar (2001), it is stated that the objectives of Higher Education in the USA do not match the objectives of Multiple Intelligence Theory. While the researcher emphasizes that all intelligence domains of students admitted to universities can be improved by multiple intelligence theory, it is reported that the criteria for admission to universities in the USA is based on the verbal/linguistic or logical/mathematical intelligence domains mostly all across the country similar to the conditions in Turkey. Kezar (2001), states that people have the rights and opportunities to receive higher education at certain levels even with personal efforts, but it is not quite possible for the students with higher intelligence domains other than verbal-linguistic and logical-mathematical intelligence to study in the prominent higher education institutions. In this context, considering the terms of accepting students into the universities in Turkey, it is difficult to say that there is a sufficient consistency between the system of student selection into higher education and multiple intelligence theory based education mentality due to the existence of a system inclined to admit students with verbal-linguistic or logical-mathematical intelligence more. Besides, the applied programs are implemented in a way to improve 
achievements in examinations, emphasis is given on verbal-linguistic or logical-mathematical intelligence, and other intelligence domains are neglected (Demircioğlu \& Güneysu, 2000). After the transition to higher education, due to the professional and specialized education process and branching studies, the existing situation is preserved rather than further developing the present intelligence domain.

\section{References}

Barnes, C., \& Mercer, G. (2005). Disability, work and welfare: challenging the social exclusion of disabled persons. Work, Employment \& Society, 19(3), 527-545. https://doi.org/10.1177/0950017005055669

Bellanca, J. (1997). Active learning handbook for multiple intelligence classrooms (pp. 1-465). USA: IRI/Skylight Training and Publishing Inc.

Bennet, M. (1996). Men's and women's self-estimates of intelligence. The Journal of Social Psychology, 136, 411-412. https://doi.org/10.1080/00224545.1996.9714021

Bolderson, H., Mabbett, D., Hvinden, B., \& van Oorschot, W. J. H. (2002). Definitions of disability in Europe: A comparative analysis: Final report. Brunel UK: Brunel University.

Burcu, E. (2017). Türkiye'de engelli bireylerin dezavantajlı konumlarına engellilik sosyolojisinin eleştirel tavriyla bakmak. Toplum ve Demokrasi, 11(24), 107-125.

Demiray, G., \& Dolu, N. (2011). Üniversite sınavına hazırlanan öğrencilerde çoklu zekânın değerlendirilmesi. Journal of Health Sciences, 20(1), 29-38.

Doğan, Y., \& Alkış, S. (2007). Sınıf öğretmeni adaylarının sosyal bilgiler derslerinde çoklu zekâ alanlarını kullanabilmelerine yönelik görüşleri. Ĕgitim Fakültesi Dergisi, 20(2), 327-339.

Ermiş, E., \& İmamoğlu, O. (2013). The effect of doing sports on the multiple intelligences of university students. International Journal of Academic Research (Part B), 5(5), 174-179. https://doi.org/10.7813/2075-4124.2013/5-5/B.26

Furnham, A., \& Fong, G. (2000). Self-estimated and psychologiacally measured intelligence: A cross-cultural and sex differences study of British and Singaporean students. North American Journal of Psychology, 2(2), 191-200.

Gardner, H. (1993). Multiple intelligence: The theory in practice. New York: Basic Books.

Gardner, H. (1999). Intelligence Reframed: Multiple Intelligences for the 21st Century. New York, NY: Basic Books.

Gülşen, C. (2015). Multiple Intelligences Areas Evaluation Scale developing study. Journal of Human Sciences, 12(2), 1918-1930. https://doi.org/10.14687/ijhs.v12i2.3469

Hahn, H. (1999). The political implications of disability definitions and data. The Psychological and Social Impact of Disability. New York: Springer Publishing Company. https://doi.org/10.1177/104420739300400203

Heiden, H. G. (1996). Niemand darf wegen seiner Behinderung benachteiligt werden - Grundrecht und Alltag: eine Bestandsaufnahme. Hamburg. Rowohlt.

Hoşgörür, V., \& Katrancı, M. (2007). Sınıf ve beden eğitimi ve spor öğretmenliği öğrencilerinin baskın zekâ alanları (Kırıkkale üniversitesi eğitim fakültesi örneği). Ondokuz Mayıs Üniversitesi Eğitim Fakültesi Dergisi, 24, 33-42.

Kezar, A. (2001). Theory of multiple intelligences: implications for higher education. Innovative Higher Education, 26(2), 141-147. https://doi.org/10.1023/A:1012292522528

Loori, A. A. (2005). Multiple intelligences: A comperative study between the preferences of males and females. Social Behavior and Personality, 33(1), 77-88. https://doi.org/10.2224/sbp.2005.33.1.77

Republic of Turkey State Statistics Institute (DİE). (2002). Türkiye Özürlüler Araştırması. Publication Number: 2913, Ankara. DİE Matbaası.

Subaş1, S. (2014). A case study on a vocabulary development program based on multiple intelligence theory. Master Thesis. Çağ University Institute of Social Sciences. Mersin/Turkey. 29.

Temiz, N. (2007). Çoklu Zekâ Kuramı Okulda ve Sinıfta - Öğretmenim, Benim, Beynim. Nobel Yayın Dă̆ııı, Ankara, 2007. 


\section{Copyrights}

Copyright for this article is retained by the author, with first publication rights granted to the journal.

This is an open-access article distributed under the terms and conditions of the Creative Commons Attribution license (http://creativecommons.org/licenses/by/4.0/). 